\title{
Utstein-style reporting of out-of-hospital cardiac arrest in the Bielsko-Biała county
}

\section{Raportowanie pozaszpitalnego nagłego zatrzymania krążenia w powiecie bielskim w oparciu o wytyczne z Utstein}

\author{
Dariusz Gach ${ }^{1}$, Jolanta U. Nowak ${ }^{2}$, Łukasz J. Krzych ${ }^{3}$ \\ ${ }^{1}$ Department of Cardiology with Intensive Care Unit, Voivodship Hospital in Bielsko-Biała, Poland \\ ${ }^{2} 3^{\text {rd }}$ Department of Cardiology, Section for Cardiovascular Diseases, Silesian Center for Heart Diseases, Zabrze, Poland \\ ${ }^{3}$ Clinical Department of Cardiac Anesthesia and Intensive Care, Silesian Center for Heart Diseases, Zabrze, Poland
}

\section{Abstract}

Introduction. Out-of-hospital cardiac arrest (OHCA) is one of the most severe medical emergencies, with significantly high both pre- and in-hospital mortality rates. The aim of the study was to assess the quality of reporting OHCA data by the Emergency Medical Service teams (EMS) in the Bielsko-Biała county, using standard ambulance dispatch cards.

Material and methods. The study included adult inhabitants of Bielsko-Biała county who suffered from OHCA in 2013. Data were retrieved from standardised PRM forms, and compared to the Utstein style template. The study group comprised 272 patients, 190 (70\%) males and 82 (30\%) females, with a median age of 71 years (IQR 60-80). The pre-hospital mortality rate was $76.5 \%$ (75.3\% in men and $79.3 \%$ in women).

Results. The potential cause of OHCA was least known, with only $22 \%$ of forms including any information concerning this issue. Suboptimal reporting on the data enabling patient identification was noted in $12 \%$ cases. There was no association between reporting style and time and place of the OHCA.

Conclusions. The overall quality of reporting of OHCA by PMR in Bielsko-Biała was good. The greatest concern was inability to identify the potential cause of the event, which can significantly influence application of adequate treatment.

Key words: out-of-hospital cardiac arrest, cardiopulmonary resuscitation, Utstein template

Folia Cardiologica 2016; 11, 4: 279-283

\section{Introduction}

Out-of-hospital cardiac arrest (OHCA) is one of the most severe medical emergencies. Despite a significant progress in immediate cardiac resuscitation methods, mortality in OHCA-affected subjects remains high, reaching up to $70 \%$ [1-3].

Management of OHCA requires multidisciplinary efforts, involving much more than just healthcare personnel. All elements are equally important in the emergency care since the final effect might depend on the function of the weakest link in the so-called chain of survival [3-5]. Assessment of circumstances under which OHCA occurred affects directly initiation of adequate resuscitation procedures and steers further specialist involvement [3-7].

Lack of unified data collection system concerning cardiovascular resuscitation initiated due to OHCA has for many years been the cause for inconsistencies in evaluation of resuscitation outcomes, and impeded introduction of procedures aimed to improve patient prognosis. In order to standardise the process of data collection and reporting cardiac arrests, American Heart Association (AHA), 
European Resuscitation Council (ERC), Heart and Stroke Foundation of Canada (HSFC), and Australian Resuscitation Council (ARC) introduced an uniform nomenclature, called "the Utstein style". These documents delineated crucial time-points of resuscitation and defined terms used for reporting the outcomes $[6,7]$. The International Liaison Committee on Resuscitation (ILCOR) is a working group aiming to produce a simple and practical template for collecting and reporting data on episodes of cardiac arrest [6]. Such unification can improve patient management by healthcare and emergency service personnel as well as by members of general public. It could also help identify weak points in emergency services, which then could be reorganised adequately.

The aim of the study was to assess the quality of reporting OHCA data by the Emergency Medical Services (EMS, in Polish: państwowe ratownictwo medyczne, PRM) in the Bielsko-Biała county using standard ambulance dispatch cards.

\section{Material and methods}

Retrospective analysis was performed using dispatch cards from the Bielsko-Biała EMS teams for 2013 ( $n=23,400$ ). Only items concerning interventions due to sudden cardiac arrest $(n=276)$ were included. Patients under 18 years of age were excluded $(n=4)$. Final analysis involved 272 dispatch cards.

The county of Bielsko-Biała has the area of $125 \mathrm{~km}^{2}$, and in 2013 had 173,699 inhabitants, including 81,991 men and 91,708 women. Seven EMS stations are located in the area, providing service in the following municipalities: Bestwina, Buczkowice, Czechowice-Dziedzice, Jasienica, Jaworze, Kozy, Porąbka, Szczyrk, Wilamowice and Wilkowice. Emergency Services in the area operate on 24/7 basis, with six specialist (S) and five basic service ( $\mathrm{P}$ - from 'podstawowy', meaning 'basic' in Polish) ambulances available.

Data were obtained from standardised dispatch cards used by EMS teams (see: supplementary file 1, available online at the journal website). These were compared to the Polish version of OHCA reporting based on the Utstein template (see: supplementary file 2 , available online at the journal website) [8]. Of all 24 variables included in the Utstein template on OHCA reporting, 22 were evaluable from the obtained dispatch cards. Standard EMS protocols do not include date of hospital discharge (or decease at the hospital) and neurological status on hospital discharge (using Cerebral Performance Category [CPC]). Dispatch cards do not have a specific box for direct cause of cardiac arrest, this feature was assessed based on diagnosis given in the dispatch card or other information available therein. No specific box for time point of first cardiac rhythm assessment is assigned in the Polish template, therefore the time point of arrival of the team was used instead. Lack of given information in the dispatch card, incomplete data or illegible notes were treated as protocol violation.

Statistical analysis was performed using Microsoft EXCEL 2010 software. Quantitative variables were expressed as median value (with interquartile range [IQR], i.e. 25-75\%). Qualitative variables were expressed as absolute and percent values. Differences between groups and trends for qualitative variables were evaluated using chi-squared test, and the statistical significance level was adopted for $p<0.05$.

\section{Results}

Episodes of OHCA were observed in 190 men (70\%) and 82 women (30\%). Median patient age was 71 years (IQR 60-80). Defibrillable arrhythmia during OHCA (VT/VF) was found in 106 subjects (39\%), whereas non-defibrillable arrhythmias were observed in 166 persons (61\%) (asystole 132 patients, pulseless electrical activity 34 persons).

Of all the affected patients, 64 persons (23.5\%) were hospitalised (47 men, 17 women), including 7 subjects admitted to haemodynamic unit (American Heart of Poland, Polsko-Amerykańskie Kliniki Serca), 26 admitted to emergency unit of the Beskid Oncology Center, City Hospital in Bielsko Biała, and 31 admitted to emergency unit of the Voivodship Hospital in Bielsko Biała. Pre-hospital mortality rate was $76.5 \%$ (75.3\% in men, $79.3 \%$ in women).

When analysing reporting adequacy in EMS dispatch cards, the least information could be obtained on the potential cause of $\mathrm{OHCA}$, with only $22 \%$ of forms including any information concerning this issue. Suboptimal reporting on the data enabling patient identification was noted in $12 \%$ cases. As for other variables, full reports were available, with minor lacks in certain cases (tab. 1). Report quality was not affected by time of day, respective days during the week, respective months or event site (house/public place/ /trafficated area) (tab. 2).

\section{Discussion}

The Utstein conferences were aimed to elaborate and provide a uniform document to enable reporting information on episodes of cardiac arrest and the applied interventions. The initiative was applauded by academic circles [3, 6-10], and attempts to introduce standardised templates were enthusiastically met both by hospital personnel and by teams providing emergency medical services. Still, optimal reporting of information concerning cardiac arrests and their circumstances in reality is lacking $[11,12]$. Reporting $\mathrm{OHCA}$ is crucial as reclaiming details of the event is rarely feasible after patient admission to hospital, on the contrary to episodes that occur in hospital. 
Table 1. Adequacy of reporting in ESM dispatch cards, according to the Utstein template

Was the date of cardiac arrest mentioned?

Was the patient identified (PESEL - national identity number/name and

surname/identity card number)

Was patient's sex reported?

Was patient's age or date of birth reported?

Was the person, who had identified/diagnosed/confirmed cardiac arrest,

Was the information on the direct (potential) cause of cardiac arrest given?

Was the information given if bystanders had previously started cardiopul-

monary resuscitation?

Was the information available whether defibrillation ad been performed by

Was the information available whether any witnesses had been present at

If witnesses had been on site, was the time of cardiac arrest given?*

Was the initial heart rhythm identified?

Was the information on heart massage (thorax compression) performed by

Was the information on defibrillation attempt given?

Was the information of ventilation given?

Was the information on administered drugs given?

Was the time of cardiac arrest/loss of consciousness recorded?*

Was the time of emergency call recorded?

Was the time of EMS' arrival on event site recorded?

Was the time of first heart rhythm analysis recorded?**

Was the information given whether the patient had pulse on arrival to the

*Time of emergency call recorded by dispatch officer; **time of EMS team arrival on site was adopted as the time of first evaluation of heart rhythm; ***if the patient was admitted to the emergency unit with no information available if heart massage was performed, it was assumed that patient had pulse on arrival to the hospital

Table 2. Selected variables and their influence on reporting adequacy*

\begin{tabular}{|c|c|c|c|c|}
\hline Variable & Time of day & Day of week & Month & Site of event \\
\hline Was any patient identification given? & $\begin{array}{c}5.73 \\
(p=0.12)\end{array}$ & $\begin{array}{c}4.84 \\
(p=0.56)\end{array}$ & $\begin{array}{c}11.19 \\
(p=0.43)\end{array}$ & $\begin{array}{c}4.51 \\
(p=0.32)\end{array}$ \\
\hline Was the patient's age or date of birth given? & $\begin{array}{c}6.64 \\
(p=0.08)\end{array}$ & $\begin{array}{c}5.93 \\
(p=0.43)\end{array}$ & $\begin{array}{c}13.89 \\
(p=0.27)\end{array}$ & $\begin{array}{c}4.23 \\
(p=0.17)\end{array}$ \\
\hline $\begin{array}{l}\text { Was the person, who had identified/diagnosed/con- } \\
\text { firmed cardiac arrest, named? }\end{array}$ & $\begin{array}{c}1.64 \\
(p=0.65)\end{array}$ & $\begin{array}{c}8.39 \\
(p=0.21)\end{array}$ & $\begin{array}{c}11.23 \\
(p=0.45)\end{array}$ & $\begin{array}{c}2.76 \\
(p=0.43)\end{array}$ \\
\hline $\begin{array}{l}\text { Was the information on the direct (potential) cause of } \\
\text { cardiac arrest given? }\end{array}$ & $\begin{array}{c}0.26 \\
(p=0.97)\end{array}$ & $\begin{array}{c}7.10 \\
(p=0.31)\end{array}$ & $\begin{array}{c}15.03 \\
(p=0,18)\end{array}$ & $\begin{array}{c}6.83 \\
(p=0.08)\end{array}$ \\
\hline
\end{tabular}

*Reported values include results of analyses using $x^{2}$ test, with levels of significance given in brackets

Accumulation of data concerning circumstances of $\mathrm{OHCA}$ in a single document permits statistical analysis at both the regional and the national level, which in turn makes it possible to compare results between different countries [11]. The analysis is crucial for improving patient care and service quality. The most important issue in daily 
practice is lack of information on the circumstances of cardiac arrest and its cause, which is invaluable for further diagnostics and management strategies. Physician on duty at the emergency department is able to initiate adequate treatment only when sufficient data is available. Decision making as to the choice of further procedures and referrals (haemodynamic unit, radiological unit versus direct admission to intensive care unit) must be swift, adequate and well grounded. Predictive factors of patient outcome include initial status, application of adequate therapeutic measures or modification of the treatment applied so far [11-13]. Inability to identify the cause of cardiac arrest due to lacking information in the report is therefore particularly worrisome, whereas lack of data concerning patient age is of lesser importance.

What should be noted, EMS teams should also be able to report on the patient outcome on admission to the emergency unit. Lack of this information impedes a meaningful evaluation of the impact of EMS intervention on patient's initial status. Furthermore, these data are of value for assessing chances of survival and degree of neurological damage in patients discharged from hospital, as suggested by the original Utstein document. If no such evaluations can be done, emergency services cannot be seriously improved, which would require specific trainings in pre-hospital interventions.
The presented study has several limitations. Firstly, data analysed herein comes from one county, and was collected under one year, therefore the results cannot be extrapolated to a wider population. Secondly, there might be difference in reporting by specialist teams and general EMS teams, which was not considered during data collection. In the presented series, approximately $70 \%$ interventions were carried out by EMS including a physician. Thirdly, ESM teams use an own reporting template, which does not include a separate entry for cause of cardiac arrest (no simple box to tick). This information was indirectly obtained, i.e. deduced, from other entries in the same dispatch card or from the description provided by the team.

\section{Conclusions}

The overall quality of reporting of OHCA by PMR in Bielsko-Biała was good. The greatest concern was inability to identify the potential cause of the event, which can significantly influence application of adequate treatment. The presented observations could make a good point in discussion on modification of the current version of the dispatch card.

\section{Conflict of interest(s)}

Authors declare no conflict of interest.

\section{Streszczenie}

Wstęp. Pozaszpitalne nagłe zatrzymanie krążenia (OHCA) należy do najcięższych stanów w medycynie i jest obarczone znamienną śmiertelnością, zarówno przed- jak i wewnątrzszpitalną. Celem pracy była ocena stopnia raportowania OHCA przez zespoły Państwowego Ratownictwa Medycznego (PRM) w powiecie bielskim na podstawie aktualnie stosowanego wzorca karty wyjazdowej.

Materiał i metody. Badaniem objęto dorosłych mieszkańców powiatu bielskiego, u których w 2013 roku wystąpiło OHCA. Dane zebrano z wykorzystaniem standardowej karty wyjazdowej PRM i porównano z wzorcem z Utstein. Badaną grupe stanowiło 272 chorych - 190 (70\%) mężczyzn i 82 (30\%) kobiety; mediana wieku 71 lat (IQR 60-80). Śmiertelność przedszpitalna wynosiła 76,5\% (75,3\% u mężczyzn i 79,3\% u kobiet).

Wyniki. Najmniej było wiadomo o potencjalnej przyczynie OHCA - tylko 22\% kart zawierało jakąkolwiek informację, na podstawie której można było zidentyfikować przyczynę zdarzenia. Raportowanie suboptymalne dotyczyło możliwości identyfikacji poszkodowanego (12\% kart). W przypadku pozostałych zmiennych odsetek raportowania był pełny lub stwierdzono pojedyncze braki. Na jakość raportowania nie wpływały czas ani miejsce zdarzenia.

Wnioski. Jakość raportowania OHCA w kartach wyjazdowych zespołów Państwowego Ratownictwa Medycznego w Bielsku-Białej jest dobra. Największe zastrzeżenia dotyczą możliwości identyfikacji potencjalnej przyczyny zatrzymania krążenia, co może znacząco wpływać na wdrożenie prawidłowego leczenia.

Słowa kluczowe: pozaszpitalne nagłe zatrzymanie krążenia, resuscytacja krążeniowo-oddechowa, wytyczne z Utstein

Folia Cardiologica 2016; 11, 4: 279-283 


\section{References}

1. Berdowski J., Berg R.A., Tijssen J.G., Koster R.W. Global incidences of out-of-hospital cardiac arrest and survival rates: systematic review of 67 prospective studies. Resuscitation 2010; 81: 1479-1487.

2. Sasson C., Rogers M.A., Dahl J., Kellermann A.L. Predictors of survival from out-of-hospital cardiac arrest: a systematic review and meta-analysis. Circ. Cardiovasc. Qual. Outcomes 2010; 3: 63-81.

3. Rea T.D., Cook A.J., Stiell I.G. et al. Predicting survival after out-of-hospital cardiac arrest: role of the Utstein data elements. Ann. Emerg. Med. 2010; 55: 249-257.

4. Iwami T., Nichol G., Hiraide A. et al. Continuous improvements in "chain of survival" increased survival after out-of-hospital cardiac arrests: a large-scale population-based study. Circulation 2009; 119: 728-734.

5. Lund-Kordahl I., Olasveengen T.M., Lorem T. et al. Improving outcome after out-of-hospital cardiac arrest by strengthening weak links of the local Chain of Survival; quality of advanced life support and post-resuscitation care. Resuscitation 2010; 81: 422-426.

6. Cummins R.O., Chamberlain D.A., Abramson N.S. et al. Recommended guidelines for uniform reporting of data from out-of-hospital cardiac arrest: the Utstein Style. A statement for health professionals from a task force of the American Heart Association, the European Resuscitation Council, the Heart and Stroke Foundation of Canada, and the Australian Resuscitation Council. Circulation 1991; 84: 960-975.

7. Perkins G.D., Jacobs I.G., Nadkarni V.M. et al. Cardiac arrest and cardiopulmonary resuscitation outcome reports: update of the Utstein Resuscitation Registry Templates for Out-of-Hospital Cardiac Arrest: a statement for healthcare professionals from a task force of the International Liaison Committee on Resuscitation (American Heart Association, European Resuscitation Council, Australian and New Zealand Council on Resuscitation, Heart and Stroke Foundation of Canada, Inter American Heart Foundation, Resuscitation Council of Southern Africa, Resuscitation Council of Asia); and the American Heart Association Emergency Cardiovascular Care Committee and the Council on Cardiopulmonary, Critical Care, Perioperative and Resuscitation. Circulation. 2015; 132: 1286-300.

8. Protokół raportowania nagłego zatrzymania krążenia. Polska Rada Resuscytacji. Available on: http://www.prc.krakow.pl/all/utstein_new. pdf. Access: 18.07.2016.

9. Estner H.L., Günzel C., Ndrepepa G. et al. Outcome after out-of-hospital cardiac arrest in a physician-staffed emergency medical system according to the Utstein style. Am. Heart J. 2007; 153: 792-799.

10. Weng T.I., Huang C.H., Ma M.H. et al. Improving the rate of return of spontaneous circulation for out-of-hospital cardiac arrests with a formal, structured emergency resuscitation team. Resuscitation 2004; 60: $137-142$.

11. Nishiyama C., Brown S.P., May S. et al. Apples to apples or apples to oranges? International variation in reporting of process and outcome of care for out-of-hospital cardiac arrest. Resuscitation 2014; 85: 1599-1609.

12. Talikowska M., Tohira H., Finn J. Cardiopulmonary resuscitation quality and patient survival outcome in cardiac arrest: a systematic review and meta-analysis. Resuscitation 2015; 96: 66-77.

13. Rudner R., Jalowiecki P., Karpel E. et al. Survival after out-of-hospital cardiac arrests in Katowice (Poland): outcome report according to the “Utstein style”. Resuscitation 2004; 61: 315-325. 